\title{
Synthesis and comparative evaluation of novel ${ }^{64} \mathrm{Cu}$-labeled high affinity cell-specific peptides for positron emission tomography imaging of tumor vasculature
}

Running Title:

Radiolabeled high affinity cell-specific peptides for PET imaging of tumor vasculature

Joseph R. Merrill ${ }^{a}$, Krzysztof Krajewski ${ }^{b}$, Hong Yuan ${ }^{a}$, Jonathan E. Frank ${ }^{a}$, David S. Lalush ${ }^{a, c}$, Cam Patterson ${ }^{d}$, Anka Veleva ${ }^{\mathrm{c}, e, *}$

a Biomedical Research Imaging Center, University of North Carolina, Chapel Hill, NC 27599 USA

${ }^{\mathrm{b}}$ Department of Biochemistry and Biophysics, University of North Carolina, Chapel Hill, NC 27599 USA

${ }^{c}$ Department of Biomedical Engineering, North Carolina State University, Raleigh, NC 27695

${ }^{d}$ NewYork Presbyterian Hospital, Weill Cornell Medical Center, New York, NY 10065 USA

e Department of Chemical and Biomolecular Engineering, North Carolina State University, Raleigh NC 27695 USA

${ }^{*}$ Corresponding author; Department of Biomedical Engineering, North Carolina State University, Raleigh, NC 27695, Tel: +1 919 5151271; Fax +1919513 3814

E-mail addresses: joseph merrill@med.unc.edu (J. R. Merrill), krzysztof krajewski@med.unc.edu (K. Krajewski), hong yuan@med.unc.edu (H. Yuan), jonathan frank@med.unc.edu (J. E. Frank), dslalush@ncsu.edu (D. S. Lalush), cpatters@nyp.org (C. Patterson), anveleva@ncsu.edu (A. Veleva) 


\begin{abstract}
Tumor angiogenesis, the formation of new tumor blood supply, has been recognized as a hallmark of cancer and represents an important target for clinical management of various angiogenesis-dependent solid tumors. Previously, by screening a bacteriophage peptide library we have discovered the FHT-peptide sequence that binds specifically to bone marrow-derived tumor vasculature with high affinity. Here in an effort to determine the potential of the FHTpeptide for in vivo positron emission tomography (PET) imaging of aggressive tumor vasculature we studied four FHT-derivatives: NOTA-FHT, NOTA-(FHT)2, NOTA-PEG-FHT, and NOTA-PEG-(FHT)2. These peptide analogs were synthesized, labeled with the PET ${ }^{64} \mathrm{Cu}$, and characterized side-by-side with small animal PET and computed tomography imaging (microPET/CT) at $1 \mathrm{~h}, 4 \mathrm{~h}$, and $24 \mathrm{~h}$ post injection in a subcutaneous Lewis lung carcinoma (LLC) tumor model. Because of its excellent in vivo kinetic properties and high tumor-to-background ratio, the ${ }^{64} \mathrm{Cu}$-NOTA-FHT radiopeptide was selected for more detailed evaluation. Blocking studies with excess of unlabeled peptide showed specific and peptide mediated ${ }^{64} \mathrm{Cu}-\mathrm{NOTA}$ FHT tumor uptake. Biodistribution experiments in the same tumor model confirmed microPET/CT imaging results. Human radiation absorbed dose extrapolated from rodent biodistribution of ${ }^{64} \mathrm{Cu}$-NOTA-FHT revealed favorable dosimetry profile. The findings from this investigation warrant further development of ${ }^{64} \mathrm{Cu}$-NOTA-FHT as a potential targeted diagnostic radiopharmaceutical for PET imaging of aggressive tumor vasculature.
\end{abstract}

Keywords: molecular imaging, tumor angiogenesis, ${ }^{64} \mathrm{Cu}$-labeled cell-specific peptides, diagnostic PET radiopharmaceuticals, radiation absorbed dose. 


\section{Introduction}

Biomaterials play an essential role in a variety of diagnostic and therapeutic procedures and perform functions to direct and control interactions with living systems that have crucial effects on overall biological performance and clinical outcomes of these procedures [1]. In most instances highly specific interactions have been regarded as key features in biomaterials design improving biocompatibility and recapitulating material-cell specific interactions [2, 3]. For example, the short Arg-Gly-Asp (RGD) tripeptide, the minimal sequence for binding to integrin receptors, has been widely utilized to impart biological function to synthetic materials and facilitate material-cell recognition events $[4,9]$. With recent advances in combinatorial, high throughput screening technologies such as bacreriophage (phage) display, new engineered peptides have been discovered that bind with high affinity to their biologic targets in a highly specific manner [10-14]. Phage display-selected, disease-specific peptides hold promise in precision medicine for use as molecularly targeted diagnostic imaging agents [15-21]. Diseasespecific, peptide-based imaging compositions have the potential to extend the clinical utility of conventional imaging techniques such as positron emission tomography (PET) by enabling integration of accurate diagnostics with therapy to achieve better outcomes.

Tumor angiogenesis, the formation of new tumor blood supply, is a hallmark of cancer and is generally associated with aggressive tumor progression and poor patient prognosis. Tumors form new blood capillaries either from pre-existing mature ones or de novo by recruiting circulating pro-angiogenic endothelial and hematopoietic precursor cells mobilized from the host bone marrow [22]. Stromal cells of bone marrow origin have been identified in the vasculature of several pre-clinical models [23-26]. In humans, bone marrow-derived endothelial cells have been detected in patients with multiple myeloma [27], breast cancer [28], non-small cell lung cancer [29], and malignant gliomas [30]. Increased levels of immature precursors in the peripheral blood of patients with breast, colon, prostate, head and neck, renal and ovarian 

progenitor cells of bone marrow origin have been exploited as a potential biomarker to guide the use of antiangiogenic therapy in cancer patients [32]. Together, these studies suggest that bone marrow-sourced, circulating pro-angiogenic tumor-homing cells actively participate in tumor angiogenesis and represent a promising target for development of novel diagnostic and therapeutic agents with improved tumor selectivity.

Screening of phage display random peptide libraries has emerged as useful and practical approach for the discovery of new peptide ligands that can bind with high affinity and specificity to a variety of targets including angiogenic blood vessels [33]. Innovative methodological selection protocols in the environment in the whole mouse have been developed to allow for improved targeting in vivo [14, 34]. Besides the optimized pharmacokinetics and in vivo binding affinity, peptides selected by unbiased phage screens typically display specificity of 10 to 100 fold for their target over background tissue $[11,13]$. Because phage display-selected ligands possess suitable pharmacokinetic properties, i.e., high affinity, tumor uptake and specificity, these targeting vectors have been actively pursued as agents for molecular imaging and non invasive tumor phenotyping [10-12, 14-19, 33]. In addition to good transport properties, and the ability to both penetrate rapidly into solid tumors and recognize hidden or rare epitopes, peptides have in general low toxicity and immunogenicity, and can be produced in large quantities at low cost.

By screening a phage display dodecapeptide library in vivo, we have previously discovered a new amino acid sequence, the FHT-peptide (Phe-His-Thr-Pro-Ser-Lys-Asn-Ser-Ala-Phe-ArgLeu), that specifically binds with high affinity to bone marrow-derived circulating tumor-homing cells [10]. Unlike the RGD sequence, widely utilized to impart specificity to integrin receptors expressed both on tumor neovasculature and tumor cells, the FHT-peptide selectively binds to a protein expressed on the surface of bone marrow-derived neovascular cells. This unique 
binding profile of the FHT-peptide provides a novel platform for developing more specific diagnostic and therapeutic agents. Here, we will test the ability of the FHT-peptide, labeled with the ${ }^{64} \mathrm{Cu}\left(\mathrm{t}_{1 / 2}=12.7 \mathrm{~h}\right)$ positron emitting radionuclide, to selectively target tumor vasculature for in vivo PET imaging. Due to its dual decay characteristics ${ }^{64} \mathrm{Cu}\left(\beta^{+}: 17.8 \%, \mathrm{E}_{\beta+\max }=653 \mathrm{keV} ; \beta\right.$ : $38.4 \%, E_{\beta-\max }=578 \mathrm{keV}$ ) has promising clinical applications both for diagnostic imaging and targeted radiotherapy. Positron emissions from a ${ }^{64} \mathrm{Cu}$-labeled peptide radiopharmaceutical will allow the oncologist to obtain diagnostic PET image assessing the malignancy and then provide personalized treatment to the patient using the same ${ }^{64} \mathrm{Cu}$-radiolabeled composition.

The goal of this study is to identify an FHT-based molecular composition for a PET imaging agent providing the highest ratio of tumor uptake to normal tissue uptake in vivo. Here we report studies that explore the pharmacokinetics and imaging characteristics of four distinct molecular constructs based on the FHT-sequence (Fig. 1) all labeled with the ${ }^{64} \mathrm{Cu}$ radionuclide for PET imaging. FHT-derivatives were prepared with the ${ }^{64} \mathrm{Cu}$-binding chelate 1,4,7-triazacuclononane 1,4,7-triacetic acid (NOTA). Modifications such as PEGylation and divalent ligand presentation were utilized to modulate in vivo distribution properties of the FHT-compositions. Both approaches, PEGylation and multivalency, are known to modify in vivo pharmacokinetics of small molecules [16, 20, 21]. FHT-peptide derivatives were prepared using solid phase peptide synthesis protocols, radiolabeled with ${ }^{64} \mathrm{Cu}$, and characterized side-by-side using dual small animal PET and computed tomography (CT) imaging (microPET/CT) at $1 \mathrm{~h}, 4 \mathrm{~h}$, and $24 \mathrm{~h}$ post injection in a subcutaneous Lewis lung carcinoma (LLC) tumor model. Biodistribution experiments were performed in the same tumor system. Peptide-specific uptake of the lead FHT-composition was demonstrated in blocking studies. Human absorbed doses for the selected lead construct were extrapolated from the rodent biodistribution. 


\section{Materials and methods}

\subsection{Reagents and analyses}

All chemicals and reagents were of analytical grade or better and were used without further purification. Rink Amide-ChemMatrix resin (loading, $0.52 \mathrm{mmol} / \mathrm{g}$ ) was purchased from PCAS BioMatrix (Quebec, Canada). 9-Fluorenylmethyloxycarbonyl (Fmoc)-protected standard amino acids, Fmoc-Lys(Fmoc)-OH, Fmoc-Lys(Mtt)-OH, di-tert-butyl dicarbonate $\left(\mathrm{Boc}_{2} \mathrm{O}\right)$, and the coupling agent 1-[Bis(dimethylamino)methylene]-1H-1,2,3-triazolo[4,5-b] pyridinium 3-oxid hexafluorophosphate (HATU) were purchased from AnaSpec (Freemont, CA) . Fmoc-NH(PEG) ${ }_{12}-\mathrm{CH}_{2} \mathrm{CH}_{2} \mathrm{CO}_{2} \mathrm{H}$ [1-(9H-fluoren-9-ylmethoxycarbonylamino)-

3,6,9,12,15,18,21,24,27,30,33,36-dodecaoxanonatria contan-39-oic acid] was purchased from Quanta Biodesign (Plain City, OH) and p-SCN-Bn-NOTA (2-S-(4-Isothiocyanatobenzyl)-1,4,7triazacyclononane-1,4,7-triacetic acid) was obtained from Macrocyclics (Dallas, TX). All other solvents and chemicals were purchased from VWR (Atlanta, GA).

The solid phase peptide synthesis was performed on Rink Amide-ChemMatrix resin using PTI Symphony (Protein Technologies, Tuscon, AZ) peptide synthesizer. Analytic highperformance liquid chromatography (HPLC) analyses were performed on a Waters Alliance HPLC system and semi-preparative HPLC purifications were conducted on a Waters 1525 HPLC system. Matrix-assisted laser desorption and ionization time of flight mass spectrometry (MALDI-TOF MS) analysis was carried out using an $\alpha$-cyano-4-hydroxycinnamic acid matrix on an $\mathrm{ABI} 4800$ mass spectrometer (Sciex, Framingham, MA).

High specific activity ${ }^{64} \mathrm{Cu}$ was obtained from the Washington University School of Medicine (St. Louis, MO) as ${ }^{64} \mathrm{CuCl}_{2}$ in $0.5 \mathrm{M} \mathrm{HCl}$. Copper-64 was produced on a CS-15 biomedical cyclotron by the ${ }^{64} \mathrm{Ni}(p, n){ }^{64} \mathrm{Cu}$ nuclear reaction using previously published methods [35]. All experiments involving the use of radioactive materials were conducted under the authorization of the Radiation Safety Committee at the University of North Carolina - Chapel Hill. 


\subsection{Peptide synthesis and characterization}

Monomeric peptide derivatives were synthesized using $20 \mu \mathrm{mol}$ of the resin, and dimeric peptide derivatives were synthesized using $12 \mu \mathrm{mol}$ of the resin. Fmoc-Lys(Mtt)-OH, Fmoc-Lys(Fmoc)-OH, and Fmoc-NH-(PEG) ${ }_{12}-\mathrm{CH}_{2} \mathrm{CH}_{2} \mathrm{CO}_{2} \mathrm{H}$ (PEG) were introduced using single $2 \mathrm{~h}$ couplings. The reactions were confirmed by ninhydrin test. All other residues were introduced using double coupling. Fmoc- groups were removed by treatment with $20 \%$ piperidine in N,N-dimethylformamide (DMF) followed by washing with DMF. The synthesis of all peptides started with Fmoc-Lys(Mtt)-OH coupling to the resin and Fmoc- group removal. For peptides containing PEG, the residue was introduced by Fmoc-NH-(PEG) ${ }_{12}-\mathrm{CH}_{2} \mathrm{CH}_{2} \mathrm{CO}_{2} \mathrm{H}$ coupling. Dimeric peptides were synthesized by coupling of Fmoc-Lys(Fmoc)-OH to either Lys(Mtt) or PEG residues and subsequent simultaneous growing of two peptide chains attached to both amine groups of this Lysine residue. After removal of the last Fmoc- group, N-terminal amino groups of all peptides were Boc- protected by mixing with $0.1 \mathrm{mmol} \mathrm{Boc}_{2} \mathrm{O}$ and $0.2 \mathrm{mmol}$ $\mathrm{N}, \mathrm{N}$-Diisopropylethylamine (DIPEA) in DMF. Mtt protective group was removed by resin treatment with a mixture of $1 \%$ trifluoroacetic acid (TFA) and $2 \%$ triisopropylsilane (TIPS) in dichlorometane (DCM) followed by washing with DCM, 0.1 M DIPEA in DMF, and DMF. Subsequently, a NOTA group was introduced into the peptides by overnight mixing of peptideresins with solution of $\mathrm{p}-\mathrm{SCN}-\mathrm{Bn}-\mathrm{NOTA}(30 \mu \mathrm{mol})$ and $0.3 \mathrm{mmol}$ diisopropylethylamine (DIEA) in $0.5 \mathrm{~mL}$ DMF. After a reaction was confirmed by ninhydrin test, resin was thoroughly washed with DMF, DCM, methanol $(\mathrm{MeOH})$, and diethyl ether and dried under vacuum overnight. The peptides were cleaved from the resin and deprotected by $2 \mathrm{~h}$ treatment with a mixture of $2.5 \%$ TIPS, 2.5\% water in TFA at room temperature. The crude peptides were precipitated from TFA solution with cold diethyl ether. After centrifugation the peptides were washed 5 times with diethyl ether, air dried, dissolved in 50\% acetonitrile $(\mathrm{CH} 3 \mathrm{CN})$ and lyophilized. The crude products were purified by semi-preparative reversed-phase HPLC (Waters Symmetry Shield column, $19 \mathrm{~mm} \times 150 \mathrm{~mm}, 5 \mu \mathrm{m}, 13 \mathrm{~nm}, \mathrm{C} 18$ ), with a 25-min gradient from $15 \% \mathrm{CH} 3 \mathrm{CN}$ in 
water $(0.1 \% \mathrm{TFA})$ to $35 \% \mathrm{CH} 3 \mathrm{CN}$ in water $(0.1 \% \mathrm{TFA})$. The flow rate was $5.0 \mathrm{~mL} / \mathrm{min}$.

Ultraviolet detection was performed at 220 and $270 \mathrm{~nm}$. The homogeneity of the peptides was determined by analytical HPLC ( Merck ChromoLith column, $2 \mathrm{~mm} \times 25 \mathrm{~mm}, 5 \mu \mathrm{m}, 30 \mathrm{~nm}$, $\mathrm{RP} 18 \mathrm{e})$, using a 10 min gradient from $5 \% \mathrm{CH} 3 \mathrm{CN}$ in water (0.1\% TFA) to $25 \% \mathrm{CH} 3 \mathrm{CN}$ in water $(0.1 \% \mathrm{TFA})$, at a flow rate of $1 \mathrm{~mL} / \mathrm{min}$ and ultraviolet detection at 220 , and $270 \mathrm{~nm}$. The purity was in the range $73 \%-95 \%$. The identity of the compounds was confirmed by MALDI-TOF mass spectrometry. Stock solutions from each peptide derivative in PBS $(1 \mathrm{~g} / \mathrm{L})$ were prepared and aliquots were used for radiolabeling.

\section{3. ${ }^{64} \mathrm{Cu}$ - radiolabeling}

For each radiolabeling reaction, approximately $2-5 \mu \mathrm{g}$ of peptide ligand was incubated with $74 \mathrm{MBq}^{64} \mathrm{CuCl}_{2}$ in $0.1 \mathrm{M}$ ammonium acetate buffer ( $\left.\mathrm{pH} 5.5\right)$ in a final volume of $200 \mu \mathrm{l}$ at $50^{\circ} \mathrm{C}$ for $30 \mathrm{~min}$. Crude radiolabeled peptide conjugates were purified on Sep-Pack light C18 reversed solid phase extraction cartridges (Waters, Milford, MA) that were pre-conditioned with $1 \mathrm{ml}$ $99.5 \%$ ethanol and $5 \mathrm{ml} \mathrm{DI}$ water. After passing the reaction mixture through the cartridge, free ${ }^{64} \mathrm{Cu}$ and any impurities were washed with $1 \mathrm{ml} \mathrm{DI}$ water and the purified product was eluted from the column with $1 \mathrm{ml} 85 \%$ ethanol. The solvent was evaporated and the solid residue was reconstituted in phosphate buffered saline (PBS) and filter sterilized immediately before injecting into the mice.

\subsection{Cell culture and animal model}

Murine Lewis lung carcinoma (LLC) cell line was obtained from ATCC (American Type Culture Collection, Manassas, VA). The LLC cells were grown in high glucose Dulbecco's modified Eagles medium (DMEM) (Gibco/Life Technologies, Grand Island, NY) supplemented 
with $10 \%$ fetal bovine serum (Gibco/Life Technologies). Cells were maintained at $37^{\circ} \mathrm{C}$ in a $5 \%$ $\mathrm{CO}_{2}$ humidified incubator. Sub-culturing was performed using standard procedures.

Five to 6-week-old, immunocompetent C57BL/6J female mice were obtained from Jackson Laboratories (Bar Harbor, ME). The mice were supplied food and water ad libitum and were used within two weeks following initial acclimation. To establish tumors, mice were anesthetized by intraperitoneal administration of $0.2 \mathrm{M}$ Avertin (approx. $0.2 \mathrm{ml}$ per mouse). LLC cells were trypsinized, washed three times in DMEM, counted, and the concentration of the cell concentration was adjusted to $2 \times 10^{6}$ cells $/ \mathrm{ml}$. Approximately $5 \times 10^{5}$ LLC cells $(250 \mu l)$ were mixed 1:1 with growth factor reduced Matrigel basement membrane matrix (BD Biosciences, Bedford, MA) for a total volume of $500 \mu \mathrm{l}$. The cell formulation was injected subcutaneously via a 22-gauge needle in the right inguinal region of each mouse. Solid tumors were established over a period of seven days, resulting in mice with approximately $0.6 \mathrm{~cm}^{3}$-sized tumors for all experiments. The formula, tumor volume $=\mathrm{a} \times \mathrm{b} \times \mathrm{b} / 2$, where $\mathrm{a}$ and $\mathrm{b}$ are the longest and the shortest perpendicular dimensions of the tumor, was used to calculate tumor volumes.

\subsection{Small animal PET/CT imaging and analysis}

MicroPET and microCT images were acquired on an eXplore Vista small animal PET/CT scanner (GE Healthcare) with center resolution of $1.2 \mathrm{~mm}$ and a $46 \mathrm{~mm}$ axial field of view. At seven days post-implantation, mice bearing s.c. LLC tumors were anesthetized with $3 \%$ isoflurane/air mixture (v/v) and injected intravenously (i.v.) via a catheter into the tail vein with approximately 7.5 MBq radiolabeled peptide at a volume of $150 \mu \mathrm{l}(\mathrm{n}=3$ for each condition). After radiopeptide administration the animals were allowed to wake up and resume normal husbandry. At $1 \mathrm{~h}, 4 \mathrm{~h}$, and $24 \mathrm{~h}$ post injection the animal was anesthetized using an isoflurane/air mixture $(\mathrm{v} / \mathrm{v})(3 \%$ for induction and 1.5\% for maintenance), placed in a head-first, prone position on a supporting cradle, and advanced into the scanner. The animal's respiratory rate was 


\subsection{Biodistribution in tumor bearing C57BL/6 mice}

Approximately $0.74 \mathrm{MBq}$ of ${ }^{64} \mathrm{Cu}-\mathrm{NOTA}-\mathrm{FHT}$ in a total volume of $150 \mu \mathrm{l}$ of saline was injected under anesthesia intravenously via a catheter in the tail vein in LLC tumor-bearing C57BL/6 mice ( $\mathrm{n}=3$ per time point) followed by conscious uptake period of $1 \mathrm{~h}, 4 \mathrm{~h}$, or $24 \mathrm{~h}$. At 


\subsection{Dosimetry calculations}

The Medical Internal Radiation Dose (MIRD) method [36] was used for estimating the absorbed dose to the following organs: liver, spleen, kidney, lungs, stomach, small and large intestines, thyroid and pancreas. The absorbed dose, with no-cross organ contributions, was calculated following the equation

$$
D_{k}=A_{o} \times \tau_{k} \times S
$$

where $D_{k}$ is the mean absorbed dose to organ region $k$ (in Gy); $A_{\circ}$ is the administered activity (in $\mathrm{Bq}$ ), $\tau_{\mathrm{k}}$ is the residence time in organ $\mathrm{k}$ (in sec), and $\mathrm{S}$ is the absorbed dose per cumulated activity (in Gy/Bq.sec). The residence times for each organ were determined based on the assumption of a similar biodistribution of activity versus time in the mouse and the human. Biodistribtion data for ${ }^{64} \mathrm{Cu}-\mathrm{NOTA}-\mathrm{FHT}$ in $\mathrm{C} 57 \mathrm{BI} / 6$ mice at $1 \mathrm{~h}, 4 \mathrm{~h}$, and $24 \mathrm{~h}$ post injection were used to calculate residence times. Physical decay was assumed for activity remaining in organs beyond 24 hours. In estimating the internal absorbed doses to human organs, the well established MIRD S-values were used for the absorbed dose of unit cumulated activity for the 
${ }^{64} \mathrm{Cu}$ radionuclide [36]. Details of this approach and the corresponding calculations are presented separately in the Data in Brief communication [37].

\begin{abstract}
2.8. Statistical analysis
All quantitative data are reported as mean \pm standard deviation (SD) of three independent measurements. Unpaired, two-tailed Student's t-tests were performed to evaluate statistical significance. $P$ values less than 0.05 were considered statistically significant.
\end{abstract}

\begin{abstract}
2.9. IACUC
All animal protocols follow the NIH guidelines for animal care and use of laboratory animals (NIH Publication \# 85-23 Rev. 1985) and were approved by the University of North Carolina at Chapel Hill Institutional Animal Care and Use Committee.
\end{abstract}

\title{
3. Results and discussion
}

\subsection{Peptide synthesis and ${ }^{64} \mathrm{Cu}$ - labeling}

We have prepared four different peptide derivatives for noninvasive visualization and assessment of tumor vasculature, NOTA-FHT, NOTA-(FHT)2, NOTA-PEG-FHT, NOTA-PEG(FHT)2, utilizing the FHT-peptide as the targeting moiety. All peptide-chelates were assembled on a solid phase peptide synthesizer on a Rink Amide-ChemMatrix resin and were designed to have the chelator NOTA attached to a side chain of a C-terminal Lys residue. A hydrophilic GlyGly-Gly-Ser (GGGS) spacer was inserted between the C-terminal end of the FHT-peptide and Lys(NOTA) to allow structural flexibility for optimal in vivo kinetics and high tumor uptake. Additionally two of the constructs, NOTA-PEG-FHT and NOTA-PEG-(FHT)2 had a monodispersed PEG ( $n=12$ MW600) moiety to modify kinetic properties in vivo. Dimeric 


\subsection{Small animal PET/CT imaging}

In vivo non invasive small animal PET/CT imaging with ${ }^{64} \mathrm{Cu}-\mathrm{NOTA}-\mathrm{FHT},{ }^{64} \mathrm{Cu}-\mathrm{NOTA}$ (FHT)2, ${ }^{64} \mathrm{Cu}-\mathrm{NOTA}-\mathrm{PEG}-\mathrm{FHT}$, and ${ }^{64} \mathrm{Cu}-\mathrm{NOTA}$-PEG-(FHT)2 was conducted in LLC subcutaneous tumor-bearing C57BL/6 immunocompetent mice. In our previous library screening experiments the same immune-competent mouse model was utilized to select the high affinity FHT-sequence that binds with high specificity to bone marrow derived tumor vasculature [14]. Discovery and development of new targeting diagnostic and therapeutic peptide sequences in vivo in mice with an intact immune system ensures that the novel peptidebased biomaterial compositions have the desired pharmacokinetic and recognition properties to overcome immune response, which is important for future clinical translation.

Representative decay-corrected transverse small animal PET/CT images acquired at $1 \mathrm{~h}$, 4h, and $24 \mathrm{~h}$ after injection of ${ }^{64} \mathrm{Cu}-\mathrm{NOTA}-\mathrm{FHT},{ }^{64} \mathrm{Cu}-\mathrm{NOTA}-(\mathrm{FHT}) 2,{ }^{64} \mathrm{Cu}-\mathrm{NOTA}-\mathrm{PEG}-\mathrm{FHT}$, and 
${ }^{64} \mathrm{Cu}-\mathrm{NOTA}$-PEG-(FHT)2 are displayed in Fig. 2A. Quantitative radioactivity data derived from the microPET/CT analysis for each FHT-composition at $1 \mathrm{~h}, 4 \mathrm{~h}$, and $24 \mathrm{~h}$ p.i. expressed as \%ID/g are summarized in Fig. 2B, C and Table 2. Tumor-to-normal tissue ratio comparisons for all four FHT-derivatives are presented in Fig. 3. It is seen from the data that renal clearance is the main route of elimination from the body for all radiopeptides with kidneys presenting the highest uptake of radioactivity with respect to other organs at every time point. All four compounds had low liver uptake at $1 \mathrm{~h}$ p.i. $\left(1.10 \pm 0.61 \% \mathrm{ID} / \mathrm{g}\right.$ for ${ }^{64} \mathrm{Cu}-\mathrm{NOTA}-\mathrm{FHT}, 1.89 \pm 1.30 \% \mathrm{ID} / \mathrm{g}$ for ${ }^{64} \mathrm{Cu}$ NOTA-(FHT)2, $2.52 \pm 0.59 \%$ ID/g for ${ }^{64} \mathrm{Cu}-\mathrm{NOTA}-\mathrm{PEG}-\mathrm{FHT}$, and $5.09 \pm 0.06 \%$ ID/g for ${ }^{64} \mathrm{Cu}-$ NOTA-PEG-(FHT)2) that stayed constantly low at all time points. Low liver uptake points to the ${ }^{64} \mathrm{Cu}-\mathrm{NOTA}$ complex being highly stable in vivo. All four compounds quickly cleared from the blood pool (0.43 $\pm 0.12 \%$ ID/g for ${ }^{64} \mathrm{Cu}-\mathrm{NOTA}-\mathrm{FHT}, 1.25 \pm 0.47 \%$ ID/g for ${ }^{64} \mathrm{Cu}-\mathrm{NOTA}-(\mathrm{FHT}) 2$, $1.82 \pm 0.17 \%$ ID/g for ${ }^{64} \mathrm{Cu}-\mathrm{NOTA}-\mathrm{PEG}-\mathrm{FHT}$, and $2.35 \pm 0.67 \% \mathrm{ID} / \mathrm{g}$ for ${ }^{64} \mathrm{Cu}-\mathrm{NOTA}-\mathrm{PEG}-$ (FHT)2 at $1 \mathrm{~h}$ p.i.) with no residual or persistent radioactivity confirming high chemical inertness and stability of the ${ }^{64} \mathrm{Cu}-\mathrm{NOTA}$ complex in vivo.

The highest tumor uptake and retention was observed for ${ }^{64} \mathrm{Cu}-\mathrm{NOTA}-\mathrm{PEG}-(\mathrm{FHT}) 2$ ( $7.93 \pm$ $1.79 \% \mathrm{ID} / \mathrm{g}$ at $1 \mathrm{~h}$ p.i., $4.42 \pm 0.45 \% \mathrm{ID} / \mathrm{g}$ at $4 \mathrm{~h}$ p.i., and $5.05 \pm 1.20 \% \mathrm{ID} / \mathrm{g}$ at $24 \mathrm{~h}$ p.i.). However, ${ }^{64} \mathrm{Cu}-\mathrm{NOTA}$-PEG-(FHT)2 demonstrated the highest kidney uptake as well $(30.42 \pm 2.22 \% \mathrm{ID} / \mathrm{g}$ at $1 \mathrm{~h}$ p.i., $29.70 \pm 1.22 \% \mathrm{ID} / \mathrm{g}$ at $4 \mathrm{~h}$ p.i., and $17.64 \pm 1.16 \% \mathrm{ID} / \mathrm{g}$ at $24 \mathrm{~h}$ p.i.). At any time point examined the tumor uptake followed the order: ${ }^{64} \mathrm{Cu}-\mathrm{NOTA}$-PEG-(FHT)2> ${ }^{64} \mathrm{Cu}-\mathrm{NOTA}-\mathrm{PEG}-\mathrm{FHT}$ $>{ }^{64} \mathrm{Cu}-\mathrm{NOTA}-(\mathrm{FHT}) 2>{ }^{64} \mathrm{Cu}-\mathrm{NOTA}-\mathrm{FHT}$. Although ${ }^{64} \mathrm{Cu}-\mathrm{NOTA}-\mathrm{FHT}$ showed only moderate uptake in tumor $(2.01 \pm 0.03 \% \mathrm{ID} / \mathrm{g}$ at $1 \mathrm{~h}$ p.i., $1.76 \pm 0.07 \% \mathrm{ID} / \mathrm{g}$ at $4 \mathrm{~h}$ p.i., and $1.72 \pm 0.51$ $\% \mathrm{ID} / \mathrm{g}$ at $24 \mathrm{~h}$ p.i.) this compound had faster renal clearance than the rest of the agents studied and cleared from the kidneys and normal organs as early as $1 \mathrm{~h}$ p.i. generating high tumor-tonormal tissue ratios (Fig. 3). ${ }^{64} \mathrm{Cu}$-NOTA-FHT produced reasonable tumor-to-liver and tumor-tokidney ratios (tumor-to-liver ratio was $1.42 \pm 0.25$ at $1 \mathrm{~h}$ p.i., $2.02 \pm 0.17$ at $4 \mathrm{~h}$ p.i., and $3.40 \pm$ 
0.26 at 24 h p.i.; tumor-to-kidney ratio was $0.65 \pm 0.03$ at $1 \mathrm{~h}$ p.i., $0.81 \pm 0.13$ at $4 \mathrm{~h}$ p.i., and 3.49 \pm 1.23 at 24 h p.i.) and high tumor-to-blood ( $3.22 \pm 1.35$ at 1 h p.i., $4.87 \pm 0.64$ at 4 h p.i., and $39.33 \pm 8.14$ at 24 h p.i.) and tumor-to-muscle ratios ( $17.03 \pm 7.41$ at 1 h p.i., $24.33 \pm 2.66$ at $4 \mathrm{~h}$ p.i., and $438.79 \pm 10.22$ at 24 h p.i.). Moreover, tumor-to-normal tissue ratios for ${ }^{64} \mathrm{Cu}-\mathrm{NOTA}-$ FHT increased with time thereby enabling improved image contrast. Although ${ }^{64} \mathrm{Cu}-\mathrm{NOTA}$-PEG(FHT)2 demonstrated enhanced tumor binding and effective avidity, the major increased renal uptake and retention is of concern. The specific cause and mechanism involved in trapping ${ }^{64} \mathrm{Cu}-\mathrm{NOTA}$-PEG-(FHT)2 in the kidneys is not presently known. In general processes of glomerular filtration (i.e., endocytosis) and readsorption in the proximal tubules (i.e., lysosomal metabolism) play a key role in kidney uptake and retention. Urine analysis may reveal the degradation profile of this tracer and identify the metabolites accumulating within the kidneys. Trapping the ${ }^{64} \mathrm{Cu}-\mathrm{NOTA}$-PEG-(FHT)2 agent or its metabolites in the tubular cells and subsequent inefficient excression in the urine creates a radiation burden to the kidneys and ultimately limits the ${ }^{64} \mathrm{Cu}-\mathrm{NOTA}$-PEG-(FHT)2 activity that can be administered safely into a patient (see also radiation absorbed dose discussion in Section 3.4).

Generally in evaluating new tumor imaging agents while the accumulation of the agent in the tumor is important it is not the absolute uptake but the contrast between target-to-non-target tissue that defines the utility of the imaging agent and determines its potential for clinical translation [21]. Within this context the microPET/CT imaging studies revealed that out of the four compounds studied ${ }^{64} \mathrm{Cu}-\mathrm{NOTA}-\mathrm{FHT}$ possesses most favorable pharmacokinetics with rapid clearance from normal tissues including the kidney and hence ${ }^{64} \mathrm{Cu}-\mathrm{NOTA}-\mathrm{FHT}$ was selected for further characterization.

To ensure that ${ }^{64} \mathrm{Cu}$-NOTA-FHT accumulates in the tumor due to specific binding of the FHT-peptide to its cellular target, ${ }^{64} \mathrm{Cu}$-NOTA-FHT was tested for binding specificity by imaging a mouse that was administered a mixture of radiolabeled and unlabeled peptide $(20 \mathrm{mg} / \mathrm{kg})(\mathrm{n}=$ 
3). The unlabeled peptide proved capable of significantly reducing tumor uptake of the radiolabeled counterpart (without blocking $2.01 \pm 0.03 \% \mathrm{ID} / \mathrm{g}$; with blocking $0.80 \pm 0.27 \% \mathrm{ID} / \mathrm{g}, \mathrm{p}$ $=0.005$ ) (Fig. 4). Furthermore uptake in normal organs under blocking conditions was similar. These data demonstrate that the observed accumulation of radioactivity in the tumor is peptide mediated.

\subsection{Rodent biodistribution studies}

Biodistribution of ${ }^{64} \mathrm{Cu}-\mathrm{NOTA}$-FHT was studied in female C67BL/6 mice bearing s.c. LLC tumors. Biodistribution data collected at $1 \mathrm{~h}, 4 \mathrm{~h}$, and $24 \mathrm{~h}$ after ${ }^{64} \mathrm{Cu}-\mathrm{NOTA}-\mathrm{FHT}$ injection are presented in Fig. 5A and table 1 in Ref. [37]. It is seen from the figure that ${ }^{64} \mathrm{Cu}$-NOTA-FHT radioactivity is cleared quickly from the blood pool, muscle, liver, spleen, kidney, lungs, heart, stomach, small intestine, large intestine, bone, thyroid, and pancreas.. The highest uptake at $1 \mathrm{~h}$ p.i. occurred in the kidneys $(5.08 \pm 0.84 \% \mathrm{ID} / \mathrm{g})$, followed by lungs $(2.00 \pm 0.19 \% \mathrm{ID} / \mathrm{g})$ and liver ( $1.63 \pm 0.24 \% \mathrm{ID} / \mathrm{g}$ ). However, kidney, lungs, and liver radioactivity cleared rapidly. Moreover, little to no ${ }^{64} \mathrm{Cu}$-FHT-NOTA bone uptake was observed over time. This low bone activity background may proof useful in enabling enhanced contrast for detecting metastatic spreads which in many tumor types are primarily found in bone. The radioactivity of the tumor was reasonable and persisted up to $24 \mathrm{~h}$ p.i. $(0.42 \pm 0.03 \% \mathrm{ID} / \mathrm{g}$ at $1 \mathrm{~h}$ p.i., $0.43 \pm 0.22 \% \mathrm{ID} / \mathrm{g}$ at $4 \mathrm{~h}$ p.i., and $0.37 \pm 0.08 \% \mathrm{ID} / \mathrm{g}$ at $24 \mathrm{~h}$ p.i.) confirming the findings from the microPET/CT imaging.

A separate blocking study was conducted at $1 \mathrm{~h}$ after injection of a mixture of ${ }^{64} \mathrm{Cu}$-NOTAFHT and excess of unlabeled NOTA-FHT $(20 \mathrm{mg} / \mathrm{kg})(\mathrm{n}=3)$. Biodistribution of ${ }^{64} \mathrm{Cu}-\mathrm{NOTA}-\mathrm{FHT}$ under blocking conditions is shown in Fig. 5B. Cumulative tumor uptake in the presence of NOTA-FHT showed small but significant decrease (without blocking $0.42 \pm 0.03 \% \mathrm{ID} / \mathrm{g}$; with blocking $0.31 \pm 0.06 \% \mathrm{ID} / \mathrm{g}, \mathrm{p}=0.032$ ). These observations indicate that radioactivity accumulation in the tumor is mediated by the FHT-peptide. Under blocking conditions 
radioactivity uptake in normal organs was unchanged. This was expected since the expression of the target for the FHT-peptide is restricted to bone marrow-derived tumor vasculature. Biodistribution results are consistent with the findings from the microPET/CT studies for ${ }^{64} \mathrm{Cu}$ FHT-NOTA and confirm the unique targeting specificity of the FHT-sequence both on a molecular and tissue level.

During the last decade extensive work has been undertaken on the development of ${ }^{64} \mathrm{Cu}$ labeled radiopeptides $[6,9,17,18,21,38-40]$. Most molecular imaging studies utilize the ArgGly-Asp sequence of several extracellular matrix proteins, as the lead structure to grant specificity to integrin receptors which are overexpressed both on tumor vasculature and tumor cells. Various design approaches to optimize the lead RGD vector for improved pharmacokinetics and tumor accumulation have been devised in a variety of tumor bearing mouse models. Dumont et al [39] developed a ${ }^{64} \mathrm{Cu}-\mathrm{RGD}$ conjugate as an attractive alternative to ${ }^{18} \mathrm{~F}$-labeled RGD tracer with improved tumor-to-background ratios. Another strategy to target cellular integrin receptors is the utilization of the knottin peptide [40]. Nielsen et al prepared the ${ }^{64} \mathrm{Cu}$-DOTA-knottin tracer and conducted head-to-head comparison with FDG in a transgenic mouse model of lung cancer. ${ }^{64} \mathrm{Cu}$-DOTA-knottin $2.5 \mathrm{~F}$ tracer produced statistically higher tumorto background rations compared to FDG. Although our findings are not directly comparable to those reported in the literature due to different chelation chemistries, target vector modifications. and different tumor models, a distinct feature of the ${ }^{64} \mathrm{Cu}-\mathrm{NOTA}-\mathrm{FHT}$ imaging tracer developed here is dramatically improved contrast due to higher tumor-to-background ratios. The FHTradiopeptide binds specifically to its target with high affinity in vivo and is retained in the tumor vasculature. At the same time it clears quickly from normal tissue. This fast clearance is expected to limit the absorbed dose to healthy tissues in humans as discussed in the next section. 


\subsection{Dosimetry calculations}

${ }^{64} \mathrm{Cu}-\mathrm{NOTA}$-FHT human absorbed dose estimates were based on the biodistribution of the radiopeptide in C57BL/6 mice at $1 \mathrm{~h}$ p.i., $4 \mathrm{~h}$ p.i., and $24 \mathrm{~h}$ p.i. Activity trapped in an organ after 24 hours was considered to be cleared only by physical decay of ${ }^{64} \mathrm{Cu}$.Further, the assumption was made that the mouse distribution determined at various time points is the same as the human distribution (for detailed analysis see Ref. [37]). The radiation absorbed doses in liver, spleen, kidney, lungs, stomach, small and large intestines, thyroid and pancreas in mGy per MBq of injected ${ }^{64} \mathrm{Cu}$-NOTA-FHT radioactivity are summarized in Table 3. Based on these data kidneys are the dose-limiting organ with an average radiation dose $0.191 \mathrm{mGy} / \mathrm{MBq}$. The relatively small absorbed dose to the normal organs allows for the safe injection of $500-800 \mathrm{MBq}$ which is sufficient for clinical PET imaging. Because of its favorable dosimetry profile ${ }^{64} \mathrm{Cu}-\mathrm{NOTA}-\mathrm{FHT}$ appears very promising for clinical translation.

\section{Conclusions}

We report on the synthesis and characterization of four new ${ }^{64} \mathrm{Cu}$-labeled peptide compositions for PET imaging of tumor vasculature that all incorporate the phage displayselected high affinity, cell-specific FHT-peptide. Our results reveal that the ${ }^{64} \mathrm{Cu}-\mathrm{NOTA}$-FHT derivative demonstrates superior pharmacokinetic properties with rapid clearance from normal tissues including the kidneys resulting in high tumor-to-normal tissue ratios and improved image contrast. Further, our studies indicate that the unique imaging contrast is specifically enabled by the FHT-peptide. The low absorbed dose ${ }^{64} \mathrm{Cu}-\mathrm{NOTA}$-FHT profile highlights potential clinical utility. Further development of ${ }^{64} \mathrm{Cu}-\mathrm{NOTA}-\mathrm{FHT}$ as novel targeted radiopharmaceutical for diagnostic PET imaging of aggressive tumor vasculature is warranted. 


\section{Acknowledgements}

Research presented in this publication was supported by the National Science

Foundation with Award No: 1321424. 


\section{References}

[1] Williams DF. On the nature of biomaterials. Biomaterials. 2009;30:5897-909.

[2] Williams D. Essential materials science. Essential Biomaterials Science. 2014:29-128.

[3] Veleva AN, Heath DE, Cooper SL, Patterson C. Selective endothelial cell attachment to peptide-modified terpolymers. Biomaterials. 2008;29:3656-61.

[4] Petrie TA, Raynor JE, Reyes CD, Burns KL, Collard DM, Garcia AJ. The effect of integrinspecific bioactive coatings on tissue healing and implant osseointegration. Biomaterials. 2008;29:2849-57.

[5] Hersel U, Dahmen C, Kessler H. RGD modified polymers: biomaterials for stimulated cell adhesion and beyond. Biomaterials. 2003;24:4385-415.

[6] Kang, C. M.; Koo, H. J.; An, G. I.; Choe, Y. S.; Choi, J. Y.; Lee, K. H.; Kim, B. T., Hybrid PET/optical imaging of integrin alpha(V)beta(3) receptor expression using a Cu-64-labeled streptavidin/biotin-based dimeric RGD peptide. Ejnmmi Research. 2015; 5.

[7] Li, K. G.; Zhang, Z. L.; Zheng, L. F.; Liu, H.; Wei, W.; Li, Z. Y.; He, Z. Y.; Larson, A. C.; Zhang, G. X., Arg-Gly-Asp-D-Phe-Lys peptide-modified PEGylated dendrimer-entrapped gold nanoparticles for targeted computed tomography imaging of breast carcinoma. Nanomedicine 2015, 10, (14), 2185-2197.

[8] Yang, G. J.; Nie, P.; Kong, Y.; Sun, H. K.; Hou, G. H.; Han, J. K., MicroPET imaging of tumor angiogenesis and monitoring on antiangiogenic therapy with an F-18 labeled RGD-based probe in SKOV-3 xenograft-bearing mice. Tumor Biology. 2015; 36, (5), 3285-3291.

[9] Chen, X. Y.; Hou, Y. P.; Tohme, M.; Park, R.; Khankaldyyan, V.; Gonzales-Gomez, I.; Bading, J. R.; Laug, W. E.; Conti, P. S., Pegylated Arg-Gly-Asp peptide: Cu-64 labeling and PET imaging of brain tumor alpha(v)beta(3)-integrin expression. J. Nucl. Med. 2004; 45, (10), 1776-1783. 
[10] Peletskaya EN, Glinsky VV, Glinsky GV, Deutscher SL, Quinn TP. Characterization of peptides that bind the tumor-associated Thomsen-Friedenreich antigen selected from bacteriophage display libraries. Journal of Molecular Biology. 1997;270:374-84.

[11] Oyama T, Sykes KF, Samli KN, Minna JD, Johnston SA, Brown KC. Isolation of lung tumor specific peptides from a random peptide library: generation of diagnostic and cell-targeting reagents. Cancer Letters. 2003;202:219-30.

[12] Koolpe M, Burgess R, Dail M, Pasquale EB. EphB receptor-binding peptides identified by phage display enable design of an antagonist with ephrin-like affinity. Journal of Biological Chemistry. 2005;280:17301-11.

[13] Veleva AN, Cooper SL, Patterson C. Selection and initial characterization of novel peptide ligands that bind specifically to human blood outgrowth endothelial cells. Biotechnology and Bioengineering. 2007;98:306-12.

[14] Veleva AN, Nepal DB, Frederick CB, Schwab J, Lockyer P, Yuan H, et al. Efficient In Vivo Selection of a Novel Tumor-Associated Peptide from a Phage Display Library. Molecules. 2011;16:900-14.

[15] Deutscher SL, Kelly KA. Imaging with Bacteriophage-derived Probes. Phage Nanobiotechnology. 2011:83-100.

[16] Singh AN, McGuire MJ, Li S, Hao G, Kumar A, Sun X, et al. Dimerization of a PhageDisplay Selected Peptide for Imaging of alpha(v)beta(6) - Integrin: Two Approaches to the Multivalent Effect. Theranostics. 2014;4:745-60.

[17] Kumar SR, Gallazzi FA, Quinn TP, Deutscher SL. Cu-64-Labeled Peptide for PET of Breast Carcinomas Expressing the Thomsen-Friedenreich Carbohydrate Antigen. Journal of Nuclear Medicine. 2011;52:1819-26.

[18] Xiong C, Huang M, Zhang R, Song S, Lu W, Flores L, II, et al. In Vivo Small-Animal PET/CT of EphB4 Receptors Using Cu-64-Labeled Peptide. Journal of Nuclear Medicine. 2011;52:241-8. 
[19] Patterson C, Frederick CB, Yuan H, Dyer LA, Lockyer P, Lalush DS, et al. Development of a New Positron Emission Tomography Tracer for Targeting Tumor Angiogenesis: Synthesis, Small Animal Imaging, and Radiation Dosimetry. Molecules. 2013;18:5594-610.

[20] Chen XY, Sievers E, Hou YP, Park R, Tohme M, Bart R, et al. Integrin alpha(V)beta(3)targeted imaging of lung cancer. Neoplasia. 2005;7:271-9.

[21] DeNardo SJ, Liu R, Albrecht H, Natarajan A, Sutcliffe JL, Anderson C, et al. (111)In-LLP2ADOTA Polyethylene Glycol-Targeting alpha 4 beta 1 Integrin: Comparative Pharmacokinetics for Imaging and Therapy of Lymphoid Malignancies. Journal of Nuclear Medicine. 2009;50:625-34.

[22] Rafii S, Lyden D, Benezra R, Hattori K, Heissig B. Vascular and haematopoietic stem cells: Novel targets for anti-angiogenesis therapy? Nature Reviews Cancer. 2002;2:826-35.

[23] Lyden D, Hattori K, Dias S, Costa C, Blaikie P, Butros L, et al. Impaired recruitment of bone-marrow-derived endothelial and hematopoietic precursor cells blocks tumor angiogenesis and growth. Nature Medicine. 2001;7:1194-201.

[24] Duda DG, Cohen KS, Kozin SV, Perentes JY, Fukumura D, Scadden DT, et al. Evidence for incorporation of bone marrow-derived endothelial cells into perfused blood vessels in tumors. Blood. 2006;107:2774-6.

[25] Aitsebaomo J, Srivastava S, Zhang H, Jha S, Wang Z, Winnik S, et al. Recombinant Human Interleukin-11 Treatment Enhances Collateral Vessel Growth After Femoral Artery Ligation. Arteriosclerosis Thrombosis and Vascular Biology. 2011;31:306-12.

[26] Lyden D, Hattori K, Dias S, Hajjar K, Manova K, Moore MAS, et al. Transplantation of bone marrow derived VEGF-responsive hematopoietic and vasculogenic precursor cells are essential to restore the angiogenic defect in Id1+/-Id3-/- knock out mice. Blood. 2000;96:529A-A. 
[27] Zhang H, Vakil V, Braunstein M, Smith ELP, Maroney J, Chen L, et al. Circulating endothelial progenitor cells in multiple myeloma: implications and significance. Blood. 2005; 105:3286-94.

[28] Furstenberger G, von Moos R, Lucas R, Thurlimann B, Senn HJ, Hamacher J, et al. Circulating endothelial cells and angiogenic serum factors during neoadjuvant chemotherapy of primary breast cancer. British Journal of Cancer. 2006;94:524-31.

[29] Dome B, Timar J, Dobos J, Meszaros L, Raso E, Paku S, et al. Identification and clinical significance of circulating endothelial progenitor cells in human non-small cell lung cancer. Cancer Research. 2006;66:7341-7.

[30] Rafat N, Beck GC, Schulte J, Tuettenberg J, Vajkoczy P. Circulating endothelial progenitor cells in malignant gliomas Clinical article. Journal of Neurosurgery. 2010;112:43-9.

[31] Roodhart JM, Langenberg MH, Vermaat JS, Lolkema MP, Baars A, Giles RH, et al. Late Release of Circulating Endothelial Cells and Endothelial Progenitor Cells after Chemotherapy Predicts Response and Survival in Cancer Patients. Neoplasia. 2010;12:8794.

[32] Duda DG, Cohen KS, di Tomaso E, Au AP, Klein RJ, Scadden DT, et al. Differential CD 146 expression on circulating versus tissue endothelial cells in rectal cancer patients: Implications for circulating endothelial and progenitor cells as biomarkers for antiangiogenic therapy. Journal of Clinical Oncology. 2006;24:1449-53.

[33] Gray BP, Brown KC. Combinatorial Peptide Libraries: Mining for Cell-Binding Peptides. Chemical Reviews. 2014;114:1020-81.

[34] Arap, W.; Pasqualini, R.; Ruoslahti, E., Cancer treatment by targeted drug delivery to tumor vasculature in a mouse model. Science. 1998; 279, (5349), 377-380.

[35] Kume M, Carey PC, Gaehle G, Madrid E, Voller T, Margenau W, et al. A semi-automated system for the routine production of copper-64. Applied Radiation and Isotopes. 2012;70:1803-6. 
[36] Snyder WS, Ford MR, Wamer GG, Watson SB, MIRD Pamphlet No. 11. Society of Nuclear Medicine: New York, NY, USA, 1975: 92-3.

[37] Merrill JR, Krajewski K, Yuan H, Frank JE, Lalush DS, Patterson C, Veleva A., Data on biodistribution and radiation absorbed dose profile of a novel $64 \mathrm{Cu}$-labeled high affinity cellspecific peptide for positron emission tomography imaging of tumor vasculature. Data in Brief. 2016, submitted.

[38] Gaertner, F. C.; Kessler, H.; Wester, H. J.; Schwaiger, M.; Beer, A. J., Radiolabelled RGD peptides for imaging and therapy. European Journal of Nuclear Medicine and Molecular Imaging. 2012; 39, 126-138.

[39] Dumont, R. A.; Deininger, F.; Haubner, R.; Maecke, H. R.; Weber, W. A.; Fani, M., Novel Cu-64- and Ga-68-Labeled RGD Conjugates Show Improved PET Imaging of alpha(v)beta(3) Integrin Expression and Facile Radiosynthesis. J. Nucl. Med. 2011; 52, (8), 1276-1284.

[40] Nielsen, C. H.; Kimura, R. H.; Withofs, N.; Tran, P. T.; Miao, Z.; Cochran, J. R.; Cheng, Z.; Felsher, D.; Kjaer, A.; Willmann, J. K.; Gambhir, S. S., PET Imaging of Tumor Neovascularization in a Transgenic Mouse Model with a Novel Cu-64-DOTA-Knottin Peptide. Cancer Res. 2010; 70, (22), 9022-9030. 
Table 1

\begin{tabular}{lcccc}
\hline Peptide Derivative & $\begin{array}{c}\text { Retention } \\
\text { Time, min }\end{array}$ & $\begin{array}{c}\text { Experimental } \\
{[\mathrm{M}+\mathrm{H}]^{+}}\end{array}$ & Chemical Formula & $\begin{array}{c}\text { Molecular Mass } \\
\text { (Theoretical) }\end{array}$ \\
\hline NOTA-FHT & 7.84 & $2240.1^{*}$ & $\mathrm{C}_{98} \mathrm{H}_{146} \mathrm{~N}_{30} \mathrm{O}_{29} \mathrm{~S}$ & 2240.49 \\
NOTA-(FHT)2 & 6.14 & 4014 & $\mathrm{C}_{176} \mathrm{H}_{263} \mathrm{~N}_{55} \mathrm{O}_{52} \mathrm{~S}$ & 4013.43 \\
NOTA-PEG-FHT & 6.79 & $2839.5^{*}$ & $\mathrm{C}_{125} \mathrm{H}_{199} \mathrm{~N}_{31} \mathrm{O}_{42} \mathrm{~S}$ & 2840.20 \\
NOTA-PEG-(FHT)2 & 7.24 & 4613 & $\mathrm{C}_{203} \mathrm{H}_{316} \mathrm{~N}_{56} \mathrm{O}_{65} \mathrm{~S}$ & 4613.15 \\
\hline
\end{tabular}

${ }^{*}$ Monoisotopic $[\mathrm{M}+\mathrm{H}]^{+}$(isotopic peaks resolved) 
Table 2

\begin{tabular}{|c|c|c|c|c|c|c|c|c|c|}
\hline $\begin{array}{l}\text { FHT-radiopeptide/Tissue } \\
\text { 64Cu-NOTA-FHT }\end{array}$ & \multicolumn{3}{|c|}{ 1h p.i. } & \multicolumn{3}{|c|}{ 4h p.i. } & \multicolumn{3}{|c|}{ 24h p.i. } \\
\hline Tumor & 2.01 & \pm & 0.03 & 1.76 & \pm & 0.07 & 1.72 & \pm & 0.51 \\
\hline Blood & 0.43 & \pm & 0.12 & 0.39 & \pm & 0.02 & 0.04 & \pm & 0.00 \\
\hline Muscle & 0.16 & \pm & 0.10 & 0.07 & \pm & 0.06 & 0.00 & \pm & 0.00 \\
\hline Liver & 1.10 & \pm & 0.61 & 0.69 & \pm & 0.39 & 0.44 & \pm & 0.27 \\
\hline Kidney & 2.27 & \pm & 0.98 & 1.61 & \pm & 0.74 & 0.57 & \pm & 0.32 \\
\hline \multicolumn{10}{|l|}{ 64Cu-NOTA-(FHT)2 } \\
\hline Tumor & 3.20 & \pm & 1.58 & 2.15 & \pm & 0.78 & 2.32 & \pm & 0.47 \\
\hline Blood & 1.25 & \pm & 0.47 & 0.85 & \pm & 0.54 & 0.35 & \pm & 0.13 \\
\hline Muscle & 0.27 & \pm & 0.11 & 0.12 & \pm & 0.09 & 0.04 & \pm & 0.01 \\
\hline Liver & 1.89 & \pm & 1.30 & 1.48 & \pm & 0.91 & 0.84 & \pm & 0.44 \\
\hline Kidney & 5.06 & \pm & 2.32 & 4.62 & \pm & 1.82 & 2.07 & \pm & 0.84 \\
\hline \multicolumn{10}{|l|}{ 64Cu-NOTA-PEG-FHT } \\
\hline Tumor & 3.54 & \pm & 0.69 & 3.48 & \pm & 1.05 & 4.29 & \pm & 0.78 \\
\hline Blood & 1.82 & \pm & 0.17 & 1.34 & \pm & 0.23 & 0.8 & \pm & 0.24 \\
\hline Muscle & 0.32 & \pm & 0.03 & 0.19 & \pm & 0.03 & 0.11 & \pm & 0.03 \\
\hline Liver & 2.52 & \pm & 0.59 & 2.57 & \pm & 0.59 & 1.74 & \pm & 0.23 \\
\hline Kidney & 23.9 & \pm & 4.68 & 18.51 & \pm & 2.09 & 7.67 & \pm & 0.44 \\
\hline \multicolumn{10}{|l|}{ 64Cu-NOTA-PEG-(FHT)2 } \\
\hline Tumor & 7.93 & \pm & 1.79 & 4.42 & \pm & 0.45 & 5.05 & \pm & 1.2 \\
\hline Blood & 2.35 & \pm & 0.67 & 2.33 & \pm & 0.21 & 1.04 & \pm & 0.04 \\
\hline Muscle & 1.15 & \pm & 0.29 & 0.41 & \pm & 0.02 & 0.13 & \pm & 0.06 \\
\hline Liver & 5.09 & \pm & 0.06 & 4.54 & \pm & 0.27 & 3.39 & \pm & 0.27 \\
\hline Kidney & 30.42 & \pm & 2.22 & 29.7 & \pm & 1.22 & 17.64 & \pm & 1.16 \\
\hline
\end{tabular}


Table 3

\begin{tabular}{lc}
\hline Tissue & $\begin{array}{c}\text { Radiation absorbed dose, } \\
\mathrm{mGy} / \mathrm{MBq}\end{array}$ \\
\hline Liver & $1.56 \mathrm{E}-02 \pm 2.59 \mathrm{E}-03$ \\
Spleen & $1.08 \mathrm{E}-03 \pm 7.26 \mathrm{E}-05$ \\
Kidney & $1.91 \mathrm{E}-01 \pm 1.35 \mathrm{E}-02$ \\
Lungs & $4.51 \mathrm{E}-03 \pm 3.09 \mathrm{E}-04$ \\
Stomach & $7.63 \mathrm{E}-03 \pm 1.89 \mathrm{E}-04$ \\
Small Intestine & $6.68 \mathrm{E}-03 \pm 8.49 \mathrm{E}-04$ \\
Large Intestine & $1.20 \mathrm{E}-02 \pm 4.14 \mathrm{E}-03$ \\
Thyroid & $1.02 \mathrm{E}-01 \pm 8.87 \mathrm{E}-03$ \\
Pancreas & $1.76 \mathrm{E}-02 \pm 3.67 \mathrm{E}-03$ \\
\hline
\end{tabular}


Fig. 1.

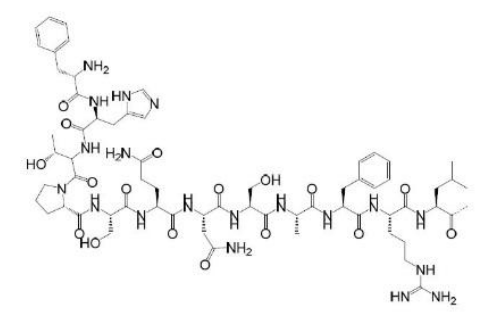

FHT - peptide

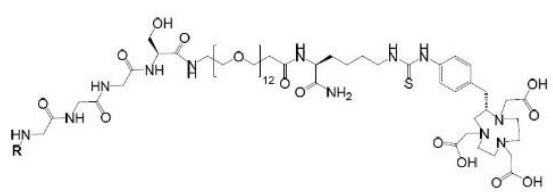

NOTA-PEG-FHT

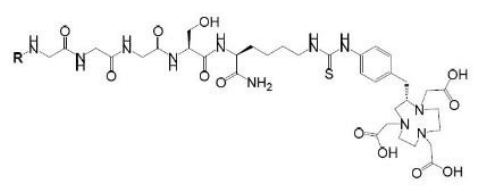

NOTA-FHT

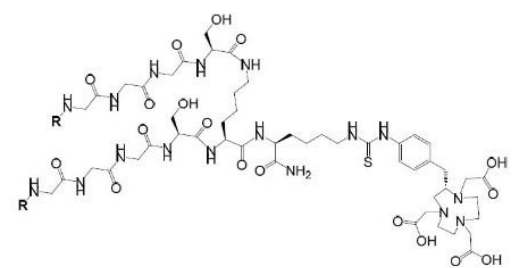

NOTA-(FHT)2

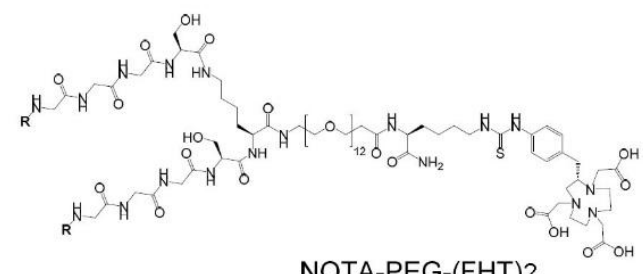

NOTA-PEG-(FHT)2 
Fig. 2.

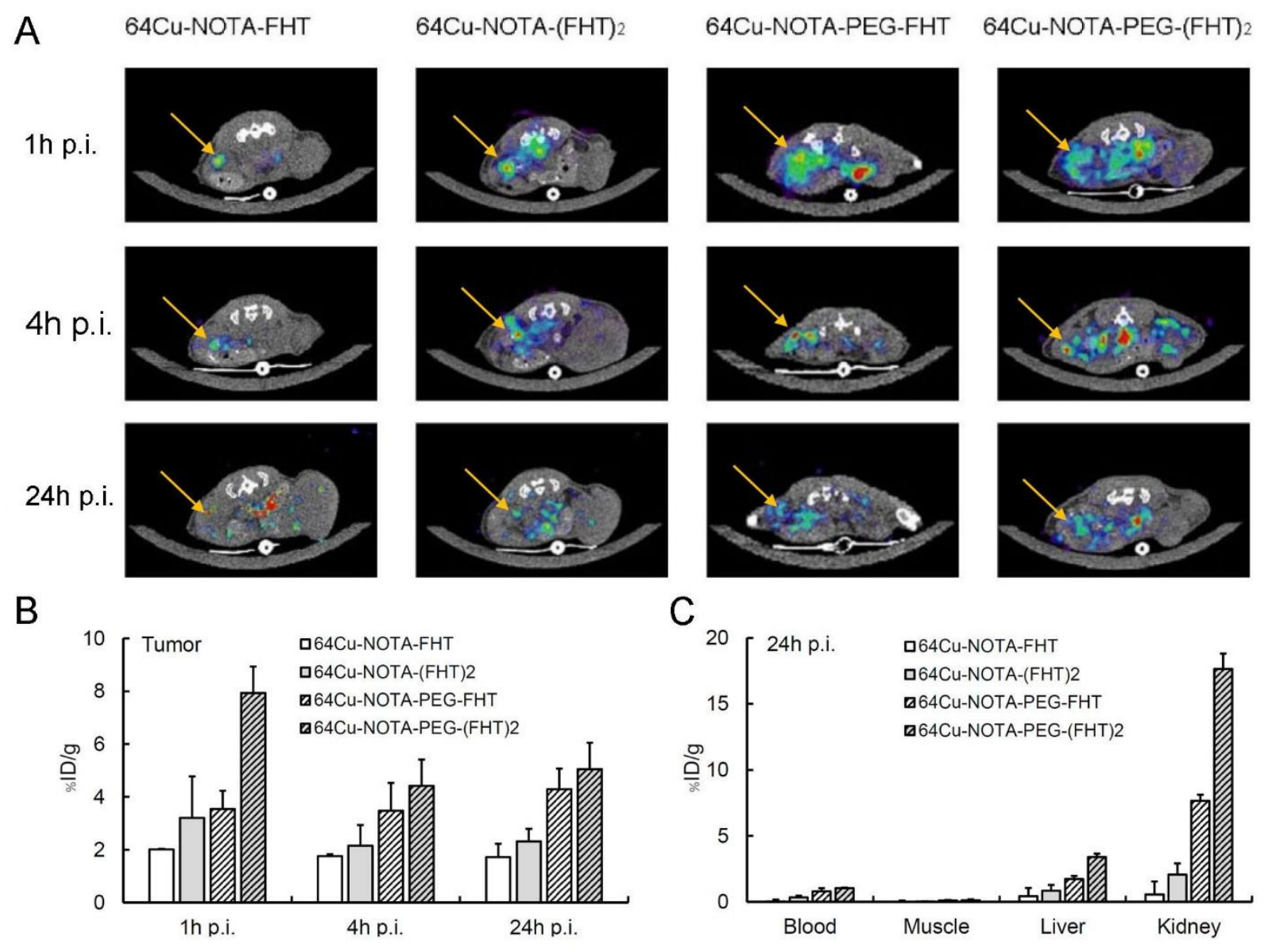


Fig. 3.
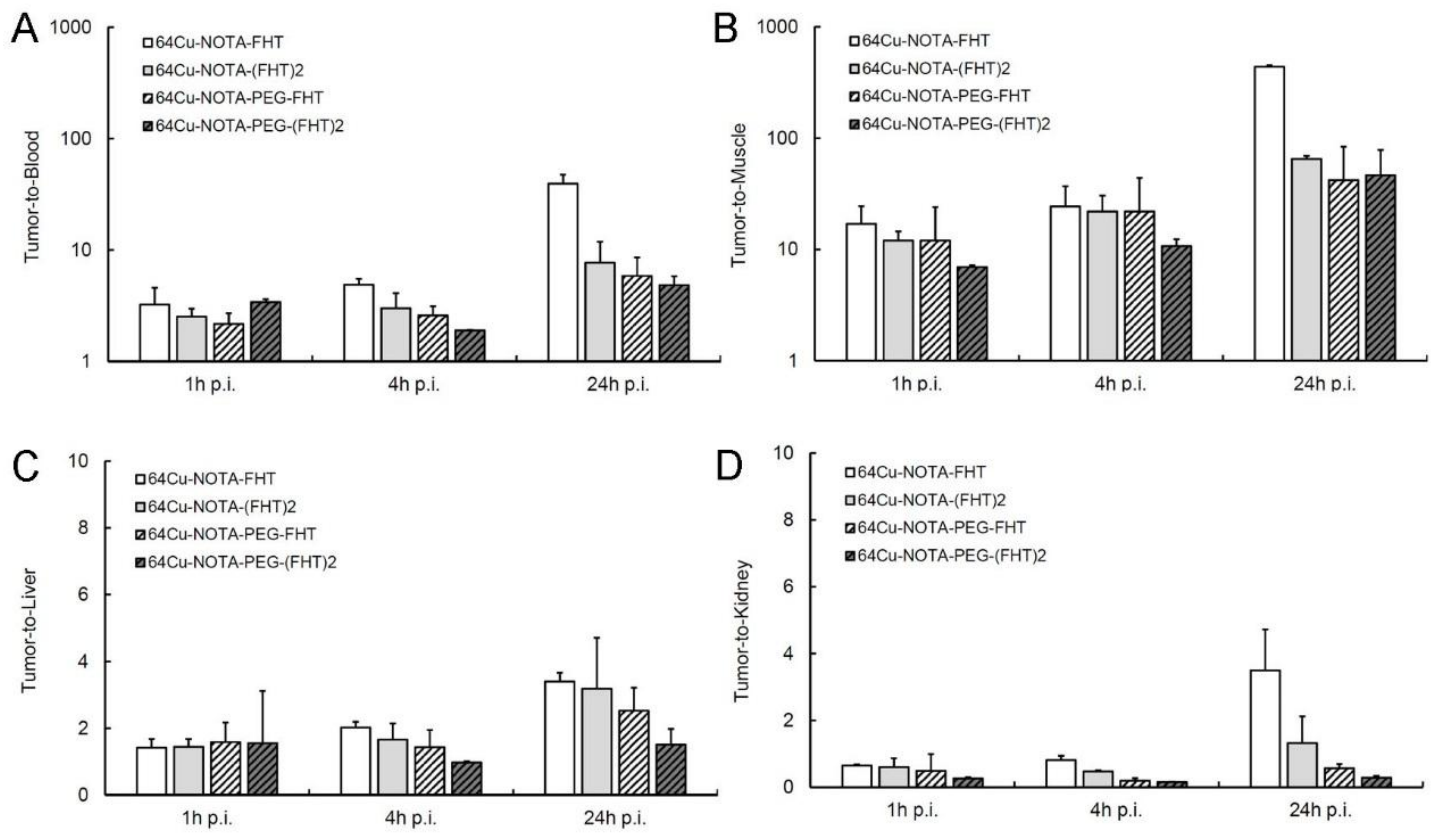
Fig. 4.

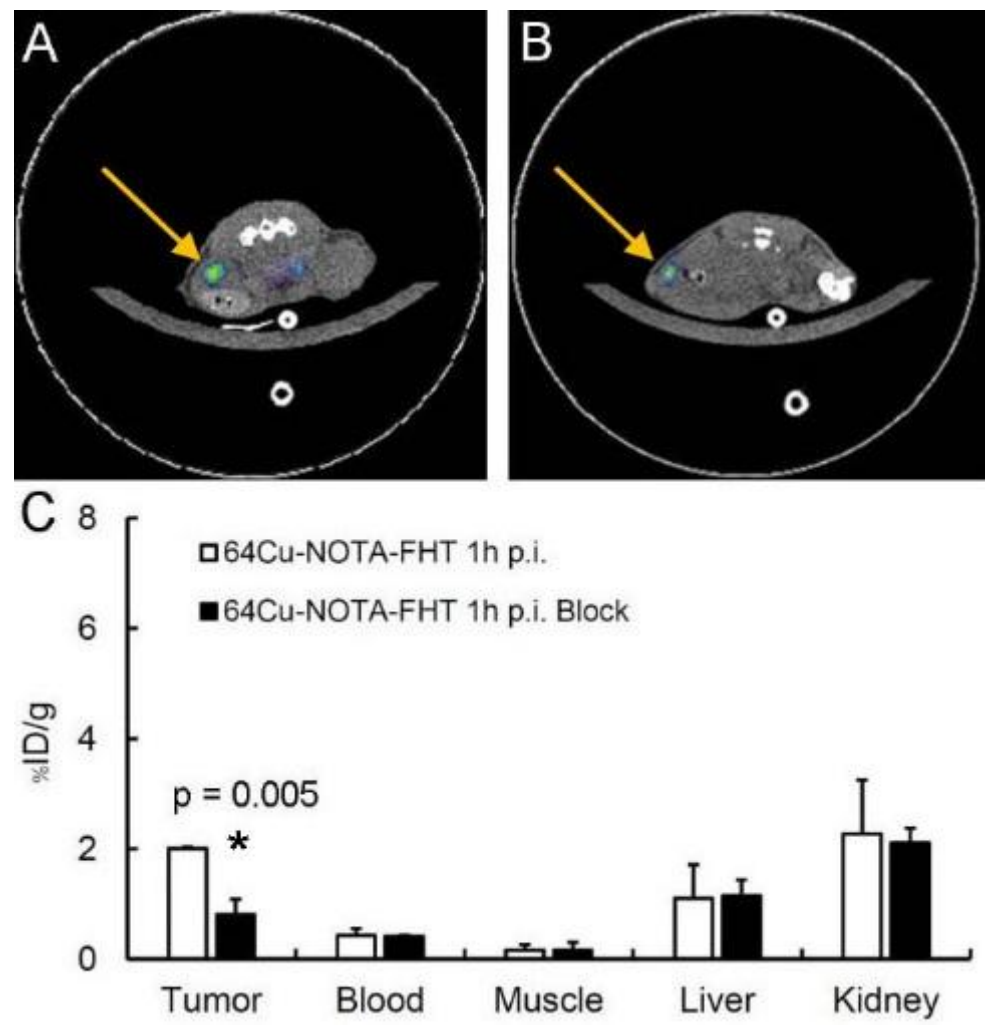


Fig. 5.
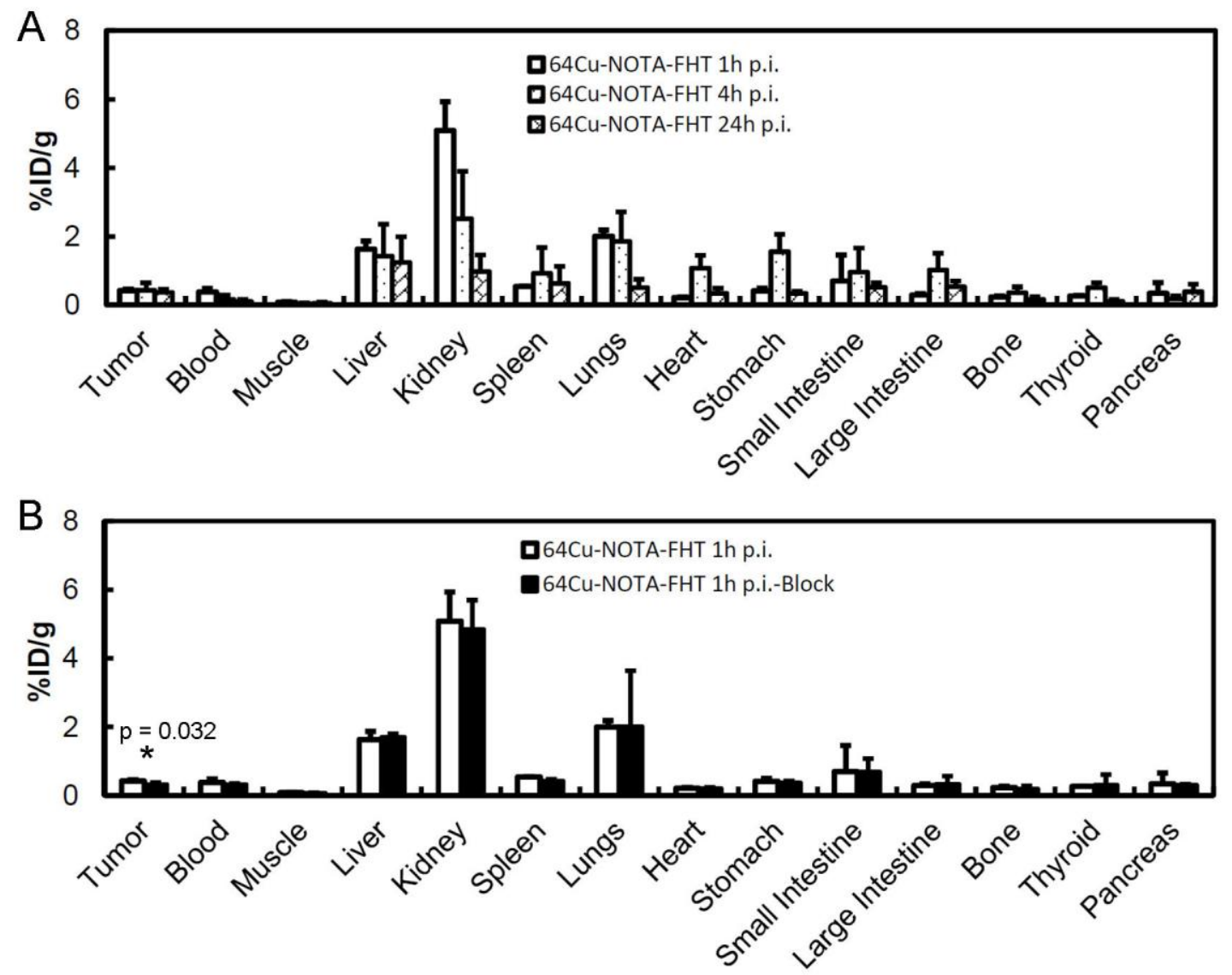


\section{Table Captions}

\section{Table 1}

Analytical data for the newly synthesized FHT-derivatives.

\section{Table 2}

Uptake of ${ }^{64} \mathrm{Cu}-\mathrm{NOTA}-\mathrm{FHT},{ }^{64} \mathrm{Cu}-\mathrm{NOTA}-(\mathrm{FHT}) 2,{ }^{64} \mathrm{Cu}-\mathrm{NOTA}-\mathrm{PEG}-\mathrm{FHT}$, and ${ }^{64} \mathrm{Cu}-\mathrm{NOTA}$-PEG(FHT)2 at $1 \mathrm{~h}$ p.i., $4 \mathrm{~h}$ p.i., and $24 \mathrm{~h}$ p.i. in blood, muscle, liver, kidney, and tumor of s.c. LLCtumor bearing mice determined by quantitative PET image analysis expressed as mean \%ID/g \pm $\operatorname{SD}(n=3)$.

\section{Table 3}

Human radiation absorbed dose estimates (in $\mathrm{mGy}$ per $\mathrm{MBq}$ ) resulting from administration of ${ }^{64} \mathrm{Cu}-\mathrm{NOTA}-\mathrm{FHT}$ extrapolated from mouse distribution data using the MIRD S-values [36] 


\section{Figure Captions}

Fig. 1. Chemical structures of FHT-peptide, NOTA-FHT, NOTA-(FHT)2, NOTA-PEG-FHT, and NOTA-PEG-(FHT)2.

Fig. 2. (A) Representative decay-corrected transverse microPET/CT images of ${ }^{64} \mathrm{Cu}-\mathrm{NOTA}$ FHT, ${ }^{64} \mathrm{Cu}-\mathrm{NOTA}-(\mathrm{FHT}) 2,{ }^{64} \mathrm{Cu}-\mathrm{NOTA}-\mathrm{PEG}-\mathrm{FHT}$, and ${ }^{64} \mathrm{Cu}-\mathrm{NOTA}-\mathrm{PEG}-(\mathrm{FHT}) 2$ at $1 \mathrm{~h}, 4 \mathrm{~h}$, and 24h after injection in LLC tumors subcutaneously implanted in the right inguinal region. Tumors are indicated by orange arrow. (B) Comparative tumor uptake, \%ID/g, of ${ }^{64} \mathrm{Cu}-\mathrm{NOTA}-\mathrm{FHT}$ (white bars), ${ }^{64} \mathrm{Cu}$-NOTA-(FHT)2 (gray bars), ${ }^{64} \mathrm{Cu}-\mathrm{NOTA}-\mathrm{PEG}-\mathrm{FHT}$ (white patterned bars), and ${ }^{64} \mathrm{Cu}$ NOTA-PEG-(FHT)2 (gray patterned bars) at $1 \mathrm{~h}, 4 \mathrm{~h}$, and $24 \mathrm{~h}$ p.i. (C) Uptake of ${ }^{64} \mathrm{Cu}-\mathrm{NOTA}-\mathrm{FHT}$, ${ }^{64} \mathrm{Cu}-\mathrm{NOTA}-(\mathrm{FHT}) 2,{ }^{64} \mathrm{Cu}-\mathrm{NOTA}-\mathrm{PEG}-\mathrm{FHT}$, and ${ }^{64} \mathrm{Cu}-\mathrm{NOTA}-\mathrm{PEG}-(\mathrm{FHT}) 2$ in other organs of interest at $24 \mathrm{~h}$ p.i. Data are presented as mean $\% \mathrm{ID} / \mathrm{g} \pm \mathrm{SD}(\mathrm{n}=3)$.

Fig. 3. (A) Tumor-to-blood, (B) tumor-to-muscle, (C) tumor-to-liver, and (D) tumor-to-kidney ratios determined from the microPET/CT images for ${ }^{64} \mathrm{Cu}-\mathrm{NOTA}-\mathrm{FHT}$ (white bars), ${ }^{64} \mathrm{Cu}-\mathrm{NOTA}$ (FHT)2 (gray bars), ${ }^{64} \mathrm{Cu}-\mathrm{NOTA}-\mathrm{PEG}-\mathrm{FHT}$ (white patterned bars), and ${ }^{64} \mathrm{Cu}-\mathrm{NOTA}-\mathrm{PEG}-(\mathrm{FHT}) 2$ (gray patterned bars) in LLC tumor bearing mice. The $y$-axis on panels $(A)$ and $(B)$ is in logarithmic scale. Tumor-to-normal organ ratios for ${ }^{64} \mathrm{Cu}-\mathrm{NOTA}-\mathrm{FHT}$ are notably higher $(\mathrm{n}=3)$.

Fig. 4. Representative decay-corrected transverse microPET/CT images in LLC tumor-bearing mice (tumors are indicated by arrows). (A) $1 \mathrm{~h}$ after injection of ${ }^{64} \mathrm{Cu}-\mathrm{NOTA}-\mathrm{FHT}$; (B) $1 \mathrm{~h}$ after coinjection of ${ }^{64} \mathrm{Cu}-\mathrm{NOTA}-\mathrm{FHT}$ and unlabeled NOTA-FHT blocking dose. (C) Uptake in tumor, blood, muscle, liver, and kidney obtained from quantitative analysis of the microPET/CT images. 
Tumor uptake of ${ }^{64} \mathrm{Cu}-\mathrm{NOTA}$-FHT is significantly reduced in the presence of NOTA-FHT $(p=0.005)$ indicating specific, FHT-mediated tumor accumulation $(n=3)$.

Fig. 5. (A) ${ }^{64}$ Cu-NOTA-FHT biodistribution in the tumor and normal organs in LLC tumor bearing C57BL/6 mice at $1 \mathrm{~h}$ p.i., $4 \mathrm{~h}$ p.i., and $24 \mathrm{~h}$ p.i. (B) ${ }^{64} \mathrm{Cu}-\mathrm{NOTA}$-FHT biodistribution in the tumor and normal organs in LLC tumor bearing C57BL/6 mice at $1 \mathrm{~h}$ p.i. in the presence of unlabeled NOTA-FHT (20 mg/kg). Small but significant decrease in accumulation of ${ }^{64} \mathrm{Cu}-\mathrm{NOTA}-\mathrm{FHT}$ in tumor but not in other organs in the presence of NOTA-FHT blocking dose points to specific tumor targeting enabled by the FHT-peptide $(p=0.032)(n=3)$. 